\title{
Clinical and demographic characteristics and functional status of the patients with fibromyalgia syndrome
}

\author{
Nilay Sahin ${ }^{1}$, Aziz Atik ${ }^{2}$, Erdal Dogan ${ }^{3}$ \\ ${ }^{1}$ Department of Physical Medicine and Rehabilitation, Balikesir University Faculty of Medicine, Balikesir, Turkey; \\ ${ }^{2}$ Department of Orthopedics and Traumatology, Balikesir University Faculty of Medicine, Balikesir, Turkey; \\ ${ }^{3}$ Department of Physical Medicine and Rehabilitation, Malatya Goverment Hospital, Malatya, Turkey
}

\begin{abstract}
OBJECTIVE: To investigate the clinical and demographic characteristics and functional status of the patients with fibromyalgia syndrome (FMS).

METHODS: Ninety-four patients with the diagnosis of FMS were included in the study. All patients were evaluated with short form 36 for quality of life (SF-36), pain, depression, benign joint hypermobility syndrome (BJHS), myofacial pain syndrome (MPS), and demogrophic characteristics. End-point measurements were SF-36 for quality of life, visual analogue scale, Beck Depression Index, anamnesis, and physical examination.

RESULTS: The majority of the patients were women who were suffering from generalised pain with a median age of 40.4. Mostly depression and sleep disorders were accompanying the syndrome. Physical examination revealed MPS and BJHS in most of the patients.
\end{abstract}

CONCLUSION: BJHS and MPS must also be investigated in patients with the diagnosis of FMS.

Key words: Depression; fibromyalgia; joint hypermobility; myofacial pain; pain; sleep disorder.

Cibromyalgia syndrome (FMS) is a syndrome - with a complex symptomatology which does not demonstrate apparent morphological characteristics [1]. Since central sensitivity involves in the pathogenesis of FMS, occasionally physicians can find it difficult to establish a diagnosis of FMS. FMS is the second most frequently established diagnosis made by the physicians specialized in the musculoskeletal system diseases. Each one of 10 patients is diagnosed as FMS among musculoskeletal physicians. Its incidence in the population has been reported as 8-15 percent. It is seen 4-8 times more frequently in women than men. FMS can be seen within age range of 18 , and 55 years, however it is more prevalent among women of the childbearing age.

Clinical symptoms are more frequently associ-

Received: July 18, 2014 Accepted: November 23, 2014 Online: December 08, 2014

Correspondence: Dr. Nilay SAHIN. Balikesir Universitesi Tip Fakultesi, Fiziksel Tip ve Rehabilitasyon Anabilim Dali, Balikesir, Turkey. 
TABLE1. Myofacial pain syndrome (MPS) diagnostic criteria

Major Criteria

1. Localized spontaneous pain

2. Spontaneous pain or alteration of perception along the pathway of the trigger point

3. Palpable taut band of the involved muscle group

4 Hypersensitivity of one tender point along the taut band

5. Restricted range of motion

\section{Mi $\square$ nor Criteria}

1. When pressed on the trigger point, emergence of spontaneously perceived pain, and altered sensations

2. Emergence of local twitchings of local muscle fibers when trigger point pricked or palpated

3. Alleviation of pain when the involved muscle is stretched or an analgesic was injected into the trigger point.

For the establishment of the diagnosis of MPS, 5 major, and at least one minor criteria should be detected.

ated with pain. Pain is generalized or regional, and it is described on the right or left side of the body, below or above the waist or along the axial skeleton. Pain persisting for at least 3 months is observed. However at the beginning, complaints of pain are related to only one region. Because of presence of neuroendocrine dysfunction playing a role in the pathology of FMS, myofacial pain syndrome, restless leg syndrome, migraine, irritable bowel syndrome, and chronic fatigue syndrome can accompany the clinical picture. Indeed, these syndromes are associated with similar pathogenetic mechanisms $[2,3]$. Symptoms seen in most of the patients are associated with these syndromes.

Psychological problems are also widely observed in FMS patients. Especially symptoms of depression or anxiety are encountered among them [4].

In the majority of the patients, sleep disorders can be seen. Therefore, complaints of fatigueness develop, and especially morning fatigueness be-
TABLE 2. Beighton criterias

Major Criteria

1. Beighton scores $\geq 4 / 9(+)$

2. presence of arthralgia in $\geq 4$ joints lasting for more than 3 months

$\mathrm{Mi} \square$ nor Criteria

1. Beighton score 1,2 or $3 / 9$ (if aged $50+$ then $0,1,2$ or $3 / 9$ )

2. Arthralgia detected in one of three affected joints or back pain or spondylosis, spondylolisthesis

3. Dislocation/sublocation of more than one joint

4. $\geq 3$ soft tissue pathologies (bursitis, tenosynovitis, epicondylitis)

5. Marfanoid appearance, and habitus (tallness, long arms, upper/lower extremity $<0.89$, arachnodactyly

6. Cutaneous strias, hyperextensibility, thin skin, abnormal scarring

7. Ophthalmological signs: Prolapsus of the eyelid or myopia or antimongoloid slant

8. Varicose veins or hernia or uterine /rectal prolapsus

For the establishment of diagnosis presence of 2 major or 1 major + 2 minor or 4 minor criteria or in 1st degree relatives 2 minor criteria should be revealed.

Beighton Criteria

Right Left

$90^{\circ}$ dorsiflexion of the

metocarpal joint

$1 \quad 1$

Passive apposition of the thumb

to the flexor aspect of the forearm $\quad 1 \quad 1$

Ability to hyperextend the arm

more than $10^{\circ}$

11

Ability to hyperextend the knee

more than $10^{\circ}$

$1 \quad 1$

Touching the palm of the hand on the ground while the foot, and the knee in extension

Total

11

For the establishment of diagnosis at least $4 / 9(+)$ criteria should be present. Since this scoring system evaluated some certain regions of the body, and it did not demonstrate the degree of hypermobility, its routine use had been severely criticized, and it was revised in 1998 so as to construct Beighton criteria. 
TABLE 3. Demographic data, and other concomitant conditions

\begin{tabular}{lccc} 
Parametres (n:94) & \multicolumn{3}{c}{ Concomitant conditions } \\
\hline Age & 40.4 & MPS & $75.2 \%$ \\
BMI & 24.4 & BJHS & $78.9 \%$ \\
Gender (female) & $89.5 \%$ & Sleep disorder & $71.3 \%$ \\
Marital status (married) & $68 \%$ & Depression & $63.5 \%$ \\
Education (university) & $48 \%$ & & \\
Profession (housewife) & $38.8 \%$ & &
\end{tabular}

comes predominant. Patients frequently complain of problems in falling asleep, especially sound sleep, and frequent arousals from their sleep at night [5].

The aim of this study is to analyze potentially concomitant diseases, clinical, demographic findings, and functional state of the patients in order not to overlook FMS in the differential diagnosis.

\section{MATERIAL AND METHOD}

A total of 94 volunteered patients who met inclusion criteria of the study and diagnosed as FMS, and consulted to the outpatient clinic because of widespread bodily pains, and complaints of poorly localized chronic pain enrolled in the study. Patients with complaints of radicular pain, neurological deficit, discal herniation, fractures, infection, malignan$c y$, serious systemic disease, and pains secondary to established diagnosis of psychotic disorders were not included in the study. From every study population informed consent forms were obtained.

General demographic information of the patients were obtained, and then sleep disorder was interrogated. Depressive state of the patients was evaluated using Beck's depression scale (BDS) [6]. Pain perception of the patients was questioned, and scored between 0 , and 10 points using visual analogue scale (VAS). For the evaluation of general health state, physical function, physical strength, pain, general health, energy (vitality), social function, emotional power, and mental health, short form-36 (SF-36) was used [7]. As a chronic pain syndrome, presence of myofacial pain syndrome (MPS) (Table 1) was inquired, and benign joint hypermobility syndrome (BJHS) was evaluated using Beighton diagnostic criteria (Table 2).

\section{RESULTS}

For statistical analysis, SPSS (Statistical Package for Social Science) Windows statistics program version 11.0. was used. As statistical methods frequencies, and descriptive methods were employed. Age range of the patients varied between 16, and 75 years (median, 40.4 years), and mean body mass index (BMI) was $24.44 \mathrm{~kg} / \mathrm{m}^{2}$. Study group consisted of female $(89.5 \%)$, and male $(10.5 \%)$ individuals. Most of the patients were married (68\%), and university graduates (48\%). MPS, and BJHS were detected in 75.2 , and $78.9 \%$ of the patients with diagnosis of FMS. Sleep disorders were detected in $71.3 \%$ of the patients, and using BDS, depression was disclosed in $63.5 \%$ of the patients (Table 3). Mobility VAS scores ranged between 4 , and 9 points (median, $6.55 \mathrm{pts}$ ), and resting VAS scores varied between 0 , and 9 points (median 5.98 pts) (Table 4). Mostly, lower physical role, pain, and energy scores were detected in SF-36 health screening of the patients (Table 5).

\section{DISCUSSION}

FMS is seen 4 to 8 -fold more frequently in women, than men [8]. FMS can be seen at every age, however it is especially more prevalent in women of the 
TABLE 4. Evaluation of pain using VAS

\begin{tabular}{lcc} 
Parametres (n:94) & $0-10$ & mean \pm SD \\
\hline VAS (mobility) & $4-9$ & $6.55 \pm 1.614$ \\
VAS (resting) & $0-9$ & $5.98 \pm 3.651$
\end{tabular}

TABLE 5. Evaluation of general health state using SF-36

\begin{tabular}{lccc} 
SF-36 subgroups $(\mathrm{n}: 94)$ & minimum & maximum & mean \pm SD \\
\hline Physical function & 15.00 & 100.00 & $69.687 \pm 21.128$ \\
Physical role & .00 & 100.00 & $38.437 \pm 37.724$ \\
Pain & 12.00 & 90.00 & $35.812 \pm 17.535$ \\
General health & 5.00 & 92.00 & $49.859 \pm 22.057$ \\
Energy & .00 & 85.00 & $38.812 \pm 20.908$ \\
Social & 12.50 & 100.00 & $62.812 \pm 22.587$ \\
Emotional & .00 & 100.00 & $51.666 \pm 40.007$ \\
Mental & 16.00 & 100.00 & $52.100 \pm 18.046$
\end{tabular}

childbearing age. It is generally seen within the age range of 18 , and 55 years. In various studies, median age of the patients was reported as 31 (27-46 yrs) years $[9,10,11]$. In our study, age range was 16-75 (mean, $40.4 \mathrm{yrs}$ ) years which was similar to those found in other studies.

Goldman observed joint laxity in patients with FMS, and fibrositis [12]. Hudson N. et al, encountered soft - tissue rheumatic disorders (FMS, bursitis, and tendinitis) in $67 \%$ of BJHS patients, and $25 \%$ of the control group, and demonstrated a statistically significant increase in soft-tissue disorders in BJHS [13]. In our study, detection of BJHS in $78.9 \%$ of FMS patients supports the outcomes of other studies.

Granges et al. encountered MPS in $68.3 \%$ of their 60 FMS patients [14]. However Gerwin et al.made diagnoses of FMS $(n=18 / 96)$ and MPS $(n=25 / 96)$ in $18.7 \%$, and $26 \%$ of the patients who consulted to their outpatient clinics, respectively. Since MPS was detected in most $(75.2 \%)$ of our patients, our results were deemed to be comparable with the results of other studies [15].

Sleep disorders can be seen in patients because of generalized pain which also worsens quality of life of the patients. MPS, and FMS are associated with sleep disorders, and interventions aiming at increasing sleep quality, also alleviate patients' pain [16]. Still in our study, a close correlation was observed between MPS, and sleep disorders.

Previous studies also demonstrated lower quality of life in patients with FMS [17]. In a study where functional state, and quality of life of FMS patients were compared with healthy controls, quality of life scores of FMS patients were found to be significantly lower than those of the healthy controls [18]. In our study, in all SF-36 subgroups which evaluated disability, poor scores were obtained especially in physical role, energy, and pain subgroups similar to those seen in other studies.

Frequently depression accompanies FMS [19, 20]. Various studies demonstrated the presence of 
neuroendocrine dysfunction in FMS [21]. Neuroendocrine dysfunction aggravates stress, adverse psychosocial factors, and pain. In these patients, higher rates of depression, and somatization symptoms relative to those without history of generalized pain were encountered. Depressive symptoms were detected in $63.5 \%$ of our patients.

In FMS chronic, moderate-severe episodes of pain are observed [21]. Similarly in our study, based on VAS scores, moderate pain which aggravated with movements was detected.

Kohl et al. investigated mental reconstruction of hot-cold tolerance, and depth of pain, and could not detect any difference between FMS patients, and control subjects as for process of cognitive reconstruction of hot-cold tolerance [22]. Flodin et al. reported that interaction, and communication between cerebral regions involving in the perception of painful stimuli, and sensorimotor regions is disrupted which resulted in defective regulation of painful stimuli [23].

Kleinman et al. investigated sleep disorders in FMS patients, and strongly evidenced that sleep disorders are seen in FMS patients. They also reported that most of the disorders seen in these patients triggered insomnia, and problems in falling asleep which worsened symptoms because of inadequate resting periods [24]. We also found a significant correlation between FMS, and sleep disorders.

Gonzalez et al. investigated the association between personal dispositions, previous traumatic events, and psychopathologies and onset of FMS, and found that personal characteristics were very closely linked with FMS, and contrary to common assumptions, previous traumatic events did not exert a strong impact on the onset of the disease [25]. In our study, personal disposition of the women in their chldbearing age was associated with the onset of FMS.

Cassisi et al. emphasized the association between FMS, and central nervous system anomalies, MPS, $\mathrm{BJHS}$, and temporomandibular joint disorders, and indicated the necessity of a multidisciplinary approach so as to relieve symptoms of pain, and restricted mobility suffered by these patients [26].
Fitzcharles et al, reported that FMS patients with low socioeconomic status experienced worse functional disability, and more severe symptoms compared with other FSM patients despite the same levels of pain, anxiety, and depression due to the differences in the perception of the disease state [27]. We also revealed the necessity of investigating additional pathologies, and supportive treatment in addition to pharmacological, and non-pharmacological treatment modalities applied for FMS patients.

\section{CONCLUSION}

In this study, we have observed that most of the patients with FMS are middle-aged women with complaints of generalized pain, and sleep disorders. This study has also revealed that these patients suffer from painful episodes while resting being more severe with movements. In some patients presence of depression was detected. In patients with established diagnosis of FMS, criteria of MPS, and BJHS should be absolutely evaluated. Moreover, it has been detected that majority of the patients experience considerable decreases especially in physical role, energy (vitality), and pain scores which necessitate multidisciplinary approach to the treatment of FMS patients.

\section{Clinical message}

In patients with established diagnosis of FMS, concomitant pathologies as MPS, and BJHS should be also investigated.

It should not be forgotten that patients with diagnosis of FMS require multidisciplinary approach.

Conflict of Interest: No conflict of interest was declared by the authors.

Financial Disclosure: The authors declared that this study has received no financial support.

\section{REFERENCES}

1. Imbierowicz K, Egle UT. Childhood adversities in patients with fibromyalgia and somatoform pain disorder. Eur J Pain 2003;7:113-9. CrossRef

2. Yunus MB. Fibromyalgia syndrome: clinical features and spec- 
trum. J Musculoskelet Pain 1994;2:5-21. CrossRef

3. Yunus MB. Suffering, science and sabotage. J Musculoskelet Pain 2004;12:3-18. CrossRef

4. Matarán-Peñarrocha GA, Castro-Sánchez AM, García GC, Moreno-Lorenzo C, Carreño TP, Zafra MD. Evid Based Complement Alternat Med 2009. [Epub ahead of print].

5. Schneider MJ, Brady DM, Perle SM. Commentary: differential diagnosis of fibromyalgia syndrome: proposal of a model and algorithm for patients presenting with the primary symptom of chronic widespread pain. J Manipulative Physiol Ther 2006;29:493-501. CrossRef

6. Hisli N."Validity and reliability of the Beck depression inventory in university students." J Psychol (Psikoloji Dergisi) 1989;7:3-13.

7. Kocyigit H, et al. "Validity and reliability of Turkish version of Short form 36: A study of a patients with romatoid disorder." Journal of Drug and Therapy (in Turkish) 1999;12:102-6.

8. İnanıcı F. Fibromiyalji ve Miyofasiyal Ağrı Sendromları. Türkiye Klinikleri J Med Sci 2005;1:11-8.

9. Baysal Ö, Altay Z, Öner T, Dilek Y, Ünal S, Kaya B. Fibromiyaljili hastalarda venlafaksin ve amitriptilinin karşılaştırılması. Hipokrat Lokomotor 2005;6:36.

10. Karakoç M, Nas K, Çevik R, Erdoğan F, Saraç AY, Coşut S. Fibromiyaljili Hastalarda Amitriptilin ve Lazer Tedavilerinin Etkinliklerinin Karşılaştırılması. Türkiye Fiziksel Tip ve Rehabilitasyon Dergisi 2001;3:47.

11. Buskila D, Neumann L, Alhoashle A, Abu-Shakra M. Fibromyalgia syndrome in men. Semin Arthritis Rheum 2000;30:47-51.

12. Goldman JA. Hypermobility and deconditioning: important links to fibromyalgia/fibrositis. South Med J 1991;84:1192-6.

13. Hudson N, Starr MR, Esdaile JM, Fitzcharles MA. Diagnostic associations with hypermobility in rheumatology patients. Br J Rheumatol 1995;34:1157-61. CrossRef

14. Granges G, Littlejohn G. Pressure pain threshold in pain-free subjects, in patients with chronic regional pain syndromes, and in patients with fibromyalgia syndrome. Arthritis Rheum 1993;36:642-6. CrossRef

15. Gerwin RD. Classification, epidemiology, and natural history of myofascial pain syndrome. Curr Pain Headache Rep
2001;5:412-20. CrossRef

16. Moldofsky HK. Disordered sleep in fibromyalgia and related myofascial facial pain conditions. Dent Clin North Am 2001;45:701-13.

17. Marques AP, Ferreira EA, Matsutani LA, Pereira CA, Assumpção A. Quantifying pain threshold and quality of life of fibromyalgia patients. Clin Rheumatol 2005;24:266-71. CrossRef

18. Çiğdem B, Yesim SA, Yesim K. Primer fibromiyalji sendromlu hastalarda yasam kalitesi: Ege Fiz Tip Reh Der 1999;5:241-5.

19. Montesó Curto MP, Ferré i Grau C, Martínez Quintana V. Fibromyalgia: beyond the depression. [Article in Spanish] Rev Enferm 2010;33:20-6. [Abstract]

20. Normand E, Potvin S, Gaumond I, Cloutier G, Corbin JF, Marchand S. Pain inhibition is deficient in chronic widespread pain but normal in major depressive disorder. J Clin Psychiatry 2011;72:219-24. CrossRef

21. Berker E, Dinçer N. Chronic pain and rehabilitation. Agri 2005;17:10-6.

22. Kohl A, Rief W, Glombiewski JA. Do fibromyalgia patients benefit from cognitive restructuring and acceptance? An experimental study. J Behav Ther Exp Psychiatry 2014;45:467-74. CrossRef

23. Flodin P, Martinsen S, Löfgren M, Bileviciute-Ljungar I, Kosek E, Fransson P. Fibromyalgia is associated with decreased connectivity between pain- and sensorimotor brain areas. Brain Connect 2014;4:587-94. CrossRef

24. Kleinman L, Mannix S, Arnold LM, Burbridge C, Howard K, McQuarrie K, et al. Assessment of sleep in patients with fibromyalgia: qualitative development of the fibromyalgia sleep diary. Health Qual Life Outcomes 2014;12:111. CrossRef

25. Gonzalez B, Baptista TM, Branco JC, Novo RF. Fibromyalgia characterization in a psychosocial approach. Psychol Health Med 2014:1-6. CrossRef

26. Cassisi G, Sarzi-Puttini P, Casale R, Cazzola M, Boccassini L, Atzeni F, et al. Pain in fibromyalgia and related conditions. Reumatismo 2014;66:72-86, CrossRef

27. Fitzcharles MA, Rampakakis E, Ste-Marie PA, Sampalis JS, Shir Y. The association of socioeconomic status and symptom severity in persons with fibromyalgia. J Rheumatol 2014;41:1398-404. 